Article

\title{
Solid State Stability and Kinetics of Degradation for Candesartan-Pure Compound and Pharmaceutical Formulation
}

\author{
Valentina Buda ${ }^{1,+}+\mathbb{C}$, Bianca Baul $^{2,+}$, Minodora Andor ${ }^{3,+}$, Dana Emilia Man ${ }^{3,+}$, \\ Adriana Ledeţi ${ }^{1, *}$, Gabriela Vlase ${ }^{4}$, Titus Vlase ${ }^{4}$, Corina Danciu ${ }^{1}$, Petru Matusz ${ }^{3}$, \\ Francisc Peter ${ }^{2}$ (D) and Ionuţ Ledeţi ${ }^{1,2, *}$ (D) \\ 1 Faculty of Pharmacy, "Victor Babeş” University of Medicine and Pharmacy, 2 Eftimie Murgu Square, \\ 300041 Timisoara, Romania; buda.valentina.oana@gmail.com (V.B.); corina.danciu@umft.ro (C.D.) \\ 2 Faculty of Industrial Chemistry and Environmental Engineering, Politehnica University of Timișoara, Vasile \\ Parvan Street 6, 300223 Timisoara, Romania; bianca.baul@student.upt.ro (B.B.); francisc.peter@upt.ro (F.P.) \\ 3 Faculty of Medicine, "Victor Babeş" University of Medicine and Pharmacy, 2 Eftimie Murgu Square, \\ 300041 Timisoara, Romania; andorminodora@gmail.com (M.A.); danaemilia@yahoo.com (D.E.M.); \\ matusz@umft.ro (P.M.) \\ 4 Research Centre for Thermal Analysis in Environmental Problems, West University of Timişoara, \\ 300115 Timisoara, Romania; gabriela.vlase@e-uvt.ro (G.V.); titus.vlase@e-uvt.ro (T.V.) \\ * Correspondence: afulias@umft.ro (A.L.); ionut.ledeti@umft.ro (I.L.); Tel.: +40-256-204-476 (A.L. \& I.L.) \\ + These authors contributed equally to this work.
}

Received: 4 December 2019; Accepted: 15 January 2020; Published: 21 January 2020

\begin{abstract}
The aim of this work was to assess the impact of an excipient in a pharmaceutical formulation containing candesartan cilexetil over the decomposition of the active pharmaceutical ingredient and to comparatively investigate the kinetics of degradation during thermolysis in an oxidative atmosphere under controlled thermal stress. To achieve this, the samples were chosen as follows: pure candesartan cilexetil and a commercial tablet of $32 \mathrm{mg}$ strength. As a first investigational tool, Universal attenuated total reflection Fourier transform infrared (UATR-FTIR) spectroscopy was chosen in order to confirm the purity and identity of the samples, as well as to check if any interactions took place in the tablet between candesartan cilexetil and excipients under ambient conditions. Later on, samples were investigated by thermal analysis, and the elucidation of the decomposition mechanism was achieved solely after performing an in-depth kinetic study, namely the use of the modified non-parametric kinetics (NPK) method, since other kinetic methods (American Society for Testing and Materials-ASTM E698, Friedman and Flynn-Wall-Ozawa) led to inadvertencies. The NPK method suggested that candesartan cilexetil and the tablet were degraded by the contribution of two steps, the main being represented by chemical degradation and the secondary being a physical transformation. The excipients chosen in the formulation seemed to have a stabilizing effect on the decomposition of the candesartan cilexetil that was incorporated into the tablet, relative to pure active pharmaceutical ingredient (API), since the apparent activation energy for the decomposition of the tablet was $192.5 \mathrm{~kJ} / \mathrm{mol}$, in comparison to $154.5 \mathrm{~kJ} / \mathrm{mol}$ for the pure API.
\end{abstract}

Keywords: candesartan cilexetil; pharmaceutical formulation; decomposition; thermal analysis; kinetic study; isoconversional methods; Friedman method; Flynn-Wall-Ozawa method; NPK method

\section{Introduction}

Candesartan is a selective, potent, and competitive antagonist of $\mathrm{AT}_{1}$ receptor (Angiotensin II receptor type 1) that is part of angiotensin II (Ang II) receptor blocker's (ARBs) family of drugs [1,2]. 
Together with losartan (the first synthesized substance of the class), olmesartan, valsartan and irbesartan, they are commonly known as biphenyl-tetrazole ARBs.

ARBs are small molecular weight pharmaceutical substances that modulate the rennin-angiotensin system and that have a high specificity for the $\mathrm{AT}_{1}$ receptor of angiotensin II. Via their mechanism of action (inhibitory pattern and dissociation rates form the receptor), they can be classified into surmountable (losartan, eprostan) or insurmountable ARBs (candesartan, irbesartan, valsartan, olmesartan, telmisartan and azilsartan) [2]. Candesartan is an oral, long-active, lipophilic compound that is available as a pro-drug; candesartan cilexetil (abbreviated CC; Figure 1) is used in formulations in order to increase their bioavailability. During gastrointestinal absorption (15\% bioavailability), it is rapidly and completely transformed into the active metabolite of candesartan through a process of ester hydrolysis. It binds in a high percentage to plasmatic proteins (95\%) and crosses the blood-brain barrier poorly. It can cross also the placental barrier. In its active form, candesartan is almost entirely excreted in feces $(67 \%)$ and urine $(33 \%)[3,4]$.

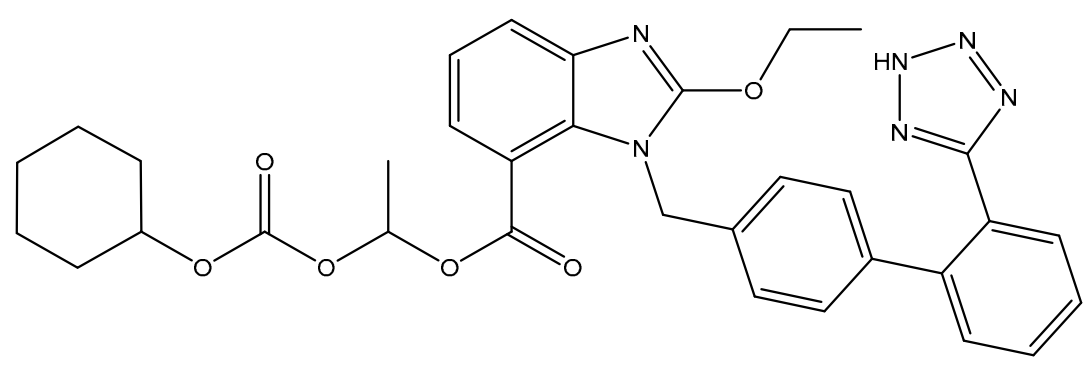

Figure 1. Structural formula of candesartan cilexetil (CC).

Acting in a dose-dependent manner, candesartan can be used in several pathologies such as essential arterial hypertension [5], ventricular hypertrophy [6], heart failure [7], diabetic nephropathy, [8] retinopathy [9], myocardial infarction [10], endothelial dysfunction [6,11], prehypertension [12], the prevention of atrial fibrillation [13], migraine prophylaxis [14], and stroke [15]. Recently, it has been shown to ameliorate brain inflammation associated with Alzheimer's disease [16] and to induce neuroprotective effects in patients suffering from Parkinson's disease [17]. Moreover, it has been shown to reduce inflammation and mucin production in patients with allergic asthma [18] and to induce benefits in a gestational hypertension mouse model [19].

CC is available in doses of 4, 8,16 and $32 \mathrm{mg}$, and it is administered in a function of the pathology (usually $4 \mathrm{mg}$ for the treatment of heart failure and $16 \mathrm{mg}$ for the treatment of hypertension) once daily in monotherapy or in combination with other classes of drugs [1,3,4]. The most common side effects reported include hypotension, hyperkalemia, impaired renal function, and allergic reactions, although other adverse effects, such as dizziness, fatigue, headache, diarrhea, impotence, upper respiratory infections, rhabdomyolysis, and angioedema [20], have been reported. CC is considered to be teratogenic, and its use should be avoided in pregnant women because it might interfere with the rennin-angiotensin-aldosterone system and decrease fetal renal function (oligohydramnios condition). Moreover, it is not known whether it is excreted into human milk, so CC administration should be avoided in lactating women $[1,20]$.

The thermal behavior of active pharmaceutical ingredients (APIs) as pure components in binary mixtures with excipients and in pharmaceutical formulations is of great importance in drug science [21-26]. Even if in the case of pharmaceuticals, the term "stability" is usually correlated with the loss of the active pharmaceutical ingredient from formulation, and "solid-state stability" can also designate the response of an API or a pharmaceutical formulation to thermal stress. However, in both cases, the decomposition of the API due to chemical processes or even physical transitions (phase transitions such as polymorphism and crystallization) in the presence of excipients dictates the shelf-life of the formulation $[27,28]$. Additionally, an adequate selection of excipients can lead to formulations with longer shelf-lives, as the presence of the excipients may have a stabilizing effect on 
the decomposition of APIs in formulation, relative to the same API as pure compound [29-34]. The literature is rather poor in presenting the physico-chemical characterization of candesartan and the prodrug CC. In 2014, Moisei et al. reported a compatibility study between several antihypertensive APIs and showed that CC is compatible with croscarmellose sodium, magnesium stearate and colloidal silica [35]. Amer et al. [36] realized a comparative evaluation of candesartan and CC by means of physicochemical properties and in vitro dissolution studies in order to replace the ester prodrug candesartan cilexetil (CC) by its active metabolite candesartan, and the results were promising. Tita et al. reported on the thermal behavior of candesartan, active substance and in pharmaceutical compounds in a dynamic nitrogen atmosphere in non-isothermal conditions, but they did so without mentioning any data regarding the strength of investigated pharmaceutical formulations and without clearly indicating if candesartan or candesartan cilexetil were studied as pure APIs; the paper mentions the cilexetil prodrug, but, though the chemical structure of the drug corresponds to candesartan, it does not correspond to the cilexetil derivative [37].

A successful development of novel cationic self-nanoemulsifying drug delivery systems of CC with improved biopharmaceutical profiles was realized by Sharma et al. and reported in 2015 [38], while Yuce et al. realized a full factorial experimental design of the immediate release of $32 \mathrm{mg}$ CC tablets in 2016 [39] that also mentioned that CC possesses a low chemical stability; however, the latter did so without carrying out a kinetic study regarding the drug's stability. Regarding the kinetic studies that have been carried out on CC, only the paper reported by Cui et al. [40] mentioned the kinetics of solvent-mediated polymorphic transitions by using Raman spectroscopy, and no study has been published regarding the solid state stability and kinetics of degradation for CC-both pure compound and pharmaceutical formulation.

Following the lack of data regarding the solid-state characterization of CC as a pure API, data regarding CC that is has been incorporated into a solid pharmaceutical formulation along with excipients, and evaluations of the kinetics of decomposition under thermal stress, we aimed to make a comparative investigation of a pure prodrug API and a commonly-used generic solid formulation containing $32 \mathrm{mg}$ of the same API per tablet. The samples were initially investigated by Universal attenuated total reflection Fourier transform infrared spectroscopy (UATR-FTIR spectroscopy) in order to confirm the purity and identities of the API and also to obtain information regarding the compatibility of the API with the excipients that were used in the solid formulation in ambient conditions; these results were later completed with a search of interactions between the components during thermal stress. The comparative thermal behavior of CC vs. a tablet containing CC as API (CCTAB) was preliminary investigated by using the thermoanalytical data that were recorded for both samples in identical experimental conditions and later by an in-depth kinetic study consisting of the use of a classic kinetic method (American Society for Testing and Materials-ASTM E698 method) and that was completed with the isoconversional methods of Friedman ( $\mathrm{Fr}$ ) and Flynn-Wall-Ozawa (FWO). The decomposition mechanism was evaluated in the last part of the study by employing the modified non-parametric kinetics (NPK) method and focused mainly on the evaluation of the stabilizing/destabilizing excipient effect over the decomposition of CC in CCTAB relative to pure CC.

\section{Materials and Methods}

\subsection{Samples and Preparation}

Pure candesartan cilexetil Chemical Reference Substances (CRS), abbreviated CC, Batch 1.1, Id 003QK7), according to European Pharmacopoeia Reference Standard, was commercial product of European Directorate for the Quality of Medicines and Healthcare EDQM, Council of Europe (Strasbourg, France) and was used without further purification.

The pharmaceutical formulation (abbreviated CCTAB) was a tablet with a strength of $32 \mathrm{mg}$ CC, which is the highest concentration available. This concentration was chosen in order to get resolute instrumental data. The tablet (of mass $260 \mathrm{mg}$ ) was crushed in an agate mortar with a pestle, 
homogenized for ten minutes, and then sieved. As excipients, the producers declared for CCTAB was the use of hydroxypropyl cellulose, calcium carboxymethyl cellulose, red iron oxide (E172), lactose monohydrate, starch from corn, macrogol 8000, and magnesium stearate.

\subsection{Spectroscopic Description of Samples}

FTIR spectra were recorded on Perkin Elmer SPECTRUM 100 device (Perkin-Elmer Applied Biosystems, Foster City, CA, USA) without an a priori preparation of the sample. The data were collected in a 4000-650 $\mathrm{cm}^{-1}$ domain on a UATR device in order to eliminate the effect of pelleting due to use of $\mathrm{KBr}$ and pressure. Spectra were built up after a number of 32 co-added scans. The spectral range $2300-1900 \mathrm{~cm}^{-1}$ represents the noise signal of the crystal and has no spectroscopic significance.

\subsection{Thermal Stability Investigations}

Thermal analysis investigations were carried out on a Perkin-Elmer DIAMOND apparatus (Perkin-Elmer Applied Biosystems, Foster City, CA, USA) for simultaneously obtaining the TG (thermogravimetric/mass curve), DTG (derivative thermogravimetric/mass derivative) and HF (heat flow curve in dynamic air atmosphere $\left(100 \mathrm{~mL} \cdot \mathrm{min}^{-1}\right)$ while using open aluminum crucibles. The analyses were carried out under non-isothermal conditions at four heating rates $\beta$, namely $5,7,10$ and $12{ }^{\circ} \mathrm{C} \cdot \mathrm{min}^{-1}$ from ambient temperature up to $400 / 500{ }^{\circ} \mathrm{C}$. To determine the thermal effects, the Differential thermal analysis (DTA) data (in $\mu \mathrm{V}$ ) were converted in HF (Heat Flow) data (in $\mathrm{mW}$ ). The HF data $(\mathrm{mW})$ were converted in normalized HF data by dividing the signal by mass of sample, thus obtaining the Differential scanning calorimetry (DSC) data (in $\mathrm{mW} \cdot \mathrm{mg}^{-1}$ ).

In order to assure the reproducibility of the thermal investigations, each analysis was carried out in duplicate, and the results were practically identical.

\subsection{Kinetic Investigations}

The kinetic study (ASTM E698, Friedman and Flynn-Wall-Ozawa methods) was carried out on the main decomposition step that took place between 190 and $310{ }^{\circ} \mathrm{C}$ while using the AKTS Thermokinetics Software Version 5.2 (AKTS AG TechnoArk, Siders, Switzerland). The mathematical background and importance of using isoconversional kinetic methods have been extensively reported in the literature [41-46]. The decomposing mechanism of CC and solid pharmaceutical formulation CCTAB was evaluated by using the modified NPK method by a protocol that has been previously reported by our research group [47-52].

\section{Results and Discussions}

In order to confirm the identity and purity of $\mathrm{CC}$, as well the presence of the API in the analyzed pharmaceutical formulation, FTIR spectra were drawn up by using the UATR technique. Some advantages of using the UATR technique are:

The samples can be analyzed without any preparation, as the technique is non-destructive and economical, since it requires small quantities of samples.

The required time for analysis is very short, since the salt pelleting that is used in classic FTIR technique is no longer required.

The technique does not require the preparation of a blank background, as in the case of pelleting technique.

The applied pressures on the surface of the ATR crystal are significantly lower than the ones used during pelleting, so polymorphic transitions and morphological modification of the analytes are not expected to occur.

\subsection{Spectroscopic Description of Samples}

The UATR-FTIR spectra recorded for CC and CCTAB are presented in Figure 2. 


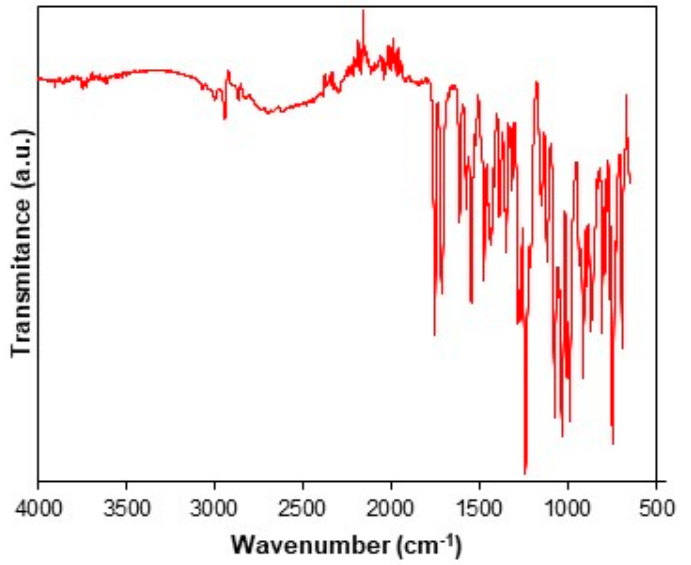

(a)

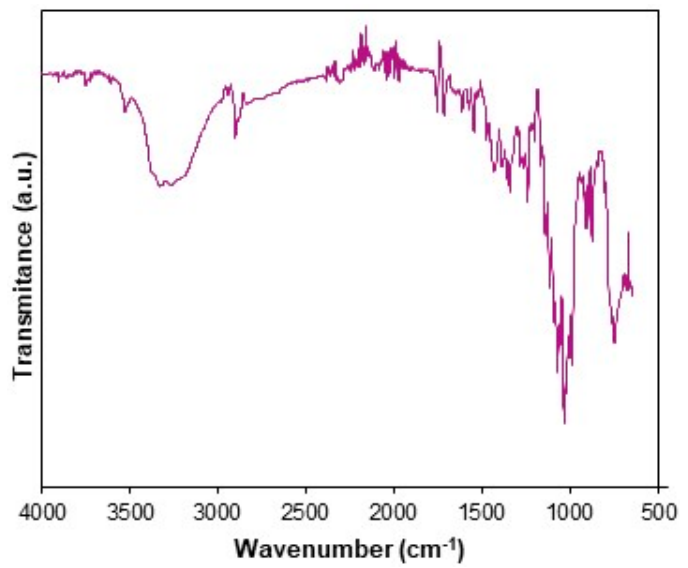

(b)

Figure 2. Universal attenuated total reflection Fourier transform infrared (UATR-FTIR) spectra recorded for analyzed samples: (a) CC and (b) tablet (CCTAB).

The UATR-FTIR spectra recorded for CC revealed the presence of the following bands: aromatic and aliphatic $\mathrm{CH}$ stretching in the spectral range of $3070-2850 \mathrm{~cm}^{-1}$, with peaks at $3067,3032,2998$, 2942 and $2863 \mathrm{~cm}^{-1}$; the stretching of the carbonyl $\mathrm{C}=\mathrm{O}$ group from the asymmetric organic carbonate $-\mathrm{OC}(=\mathrm{O}) \mathrm{O}-$ moiety showed an intense band at $1751 \mathrm{~cm}^{-1}$; an ester carbonyl group appeared as an intense band at $1713 \mathrm{~cm}^{-1}$, this being characteristic for the polymorphic Form I of CC [53]. The bending of NH appeared at $1613 \mathrm{~cm}^{-1}$, and aromatic $\mathrm{C}-\mathrm{N}$ stretching was visible at $1348 \mathrm{~cm}^{-1}$. The bands that appeared at 1240 and $1074 \mathrm{~cm}^{-1}$ were the consequences of the acyl-alkoxy tautomeric equilibrium from the $\mathrm{R} 1-\mathrm{C}(=\mathrm{O}) \mathrm{O}-\mathrm{R} 2$ moiety. The $\mathrm{C}-\mathrm{O}$ ether stretch was represented by the band at $1032 \mathrm{~cm}^{-1}$. The tetrazolyl moiety showed characteristic absorption bands in the 1640-1335 and 1200-900 cm ${ }^{-1}$ spectral regions. Due to extended conjugation of the tetrazolyl moiety with a biphenyl one, the vibrations of the $\mathrm{C}=\mathrm{C}, \mathrm{C}=\mathrm{N}$ and $\mathrm{N}=\mathrm{N}$ bonds were complex, so the individual assignment of bands to each bond could not be made. The absorption bands that appeared in the range of $1640-1335 \mathrm{~cm}^{-1}$ were due to the stretching, while the ones occurring in the $1200-900 \mathrm{~cm}^{-1}$ range were due to skeletal vibrations of the cycle, as well as by the combination bands. The data were assigned according to literature [54] and were in good agreement with previously reported studies [36,55-57].

The spectrum of CCTAB is more complex than that of pure API, since it contains more overlapping bands due to existence of excipients in the formulation. In the $3569-2989 \mathrm{~cm}^{-1}$ range, a broad band was visible due to the presence of $\mathrm{OH}$ groups in the structure of some excipients (hydroxypropyl cellulose, calcium carboxymethyl cellulose, lactose monohydrate, starch, and macrogol 8000), as well due to the water from lactose monohydrate. The characteristic bonds of CC were also present in the spectra of the tablet at the same wavenumbers or insignificantly shifted towards $\pm 3 \mathrm{~cm}^{-1}$, revealing that no interactions occurred under ambient conditions between the API and selected excipients.

\subsection{Thermal Stability Investigations}

In order to analyze the stability of CC as a pure compound and in the presence of excipients, TG/DTG/HF curves were initially recorded in an oxidative atmosphere (dynamic air), and the obtained data are presented in Figure 3. 


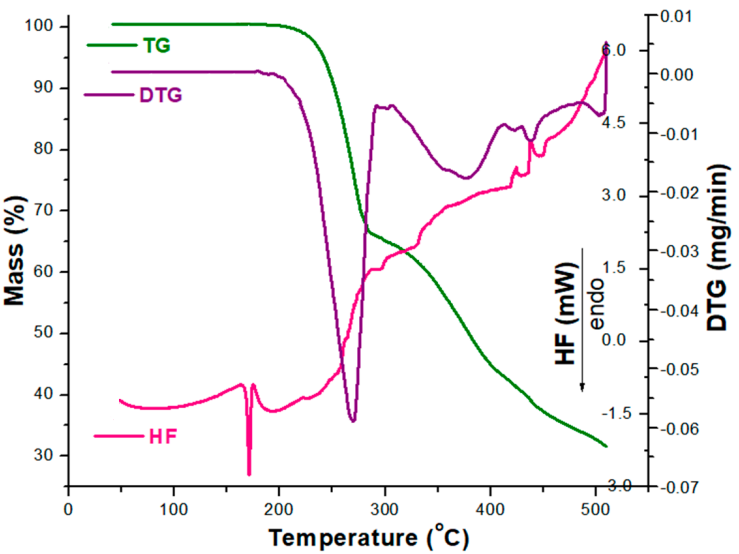

(a)

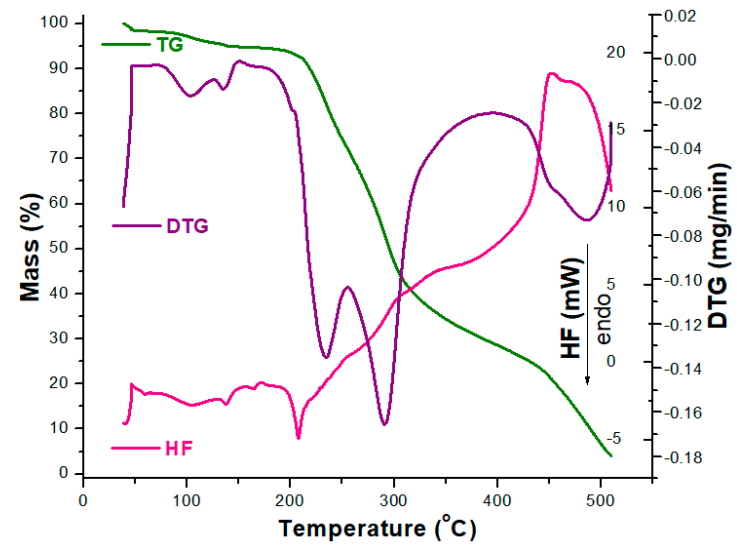

(b)

Figure 3. Thermoanalytical thermogravimetric/derivative thermogravimetric/heat flow (TG/DTG/HF) curves recorded in an oxidative synthetic air atmosphere at $\beta=5{ }^{\circ} \mathrm{C} \cdot \mathrm{min}^{-1}$ for analyzed samples: (a) CC and (b) CCTAB.

The thermoanalytical profile of CC revealed that it was thermally stable up to $164{ }^{\circ} \mathrm{C}$, when mass loss occurred with decomposition along with melting, once again confirming the existence of the polymorphic Form I of CC, as previously suggested by the UATR-FTIR spectroscopy data [53]. The main mass loss process took place in the $164-310^{\circ} \mathrm{C}$ range, with a considerable mass loss; $\Delta m=35.66 \%$. In this range, the HF curve revealed that melting occurred along with the decomposition, and the main process took place between 164 and $175^{\circ} \mathrm{C}$, with an $\mathrm{HF}_{\text {peak }}$ at $171{ }^{\circ} \mathrm{C}$. Between 310 and $510{ }^{\circ} \mathrm{C}$, the mass loss was $32.71 \%$ and was evidenced by several consecutive processes, as revealed by both the DTG and HF curves by peaks at $376,420,438$ and $503{ }^{\circ} \mathrm{C}$ (DTG) and 424,438 and $507^{\circ} \mathrm{C}$ (HF). All the processes associated with mass loss were represented by thermo-oxidations, since the HF profile was ascending and the peaks corresponded to exoergic events (Figure 3a).

The tablet (CCTAB) presented a more complex pathway of decomposition (Figure 3b), since it contained, along with CC, a considerable amount of excipients. The tablet initially lost the water found in formulation in the temperature range of $35-51{ }^{\circ} \mathrm{C}(\Delta m=1.49 \%$, endoergic event between 35 and $51{ }^{\circ} \mathrm{C}, \mathrm{HF}_{\text {peak }}$ at $42{ }^{\circ} \mathrm{C}$ ). After dehydration, the anhydrous composition of the tablet showed a narrow stability interval solely between 51 and $73^{\circ} \mathrm{C}$ when the first decomposition occurred up to $164{ }^{\circ} \mathrm{C}$ due to the presence of excipients: $\Delta m=3.77 \%$ and DTG peaks at 103 and $136^{\circ} \mathrm{C}$. In this range, the HF curve revealed several endoergic processes due to the melting of the excipients (peaks at 60 and $105^{\circ} \mathrm{C}$ ) and of the API (peak at $164{ }^{\circ} \mathrm{C}$ ). The main decomposition process took place between 164 and $369^{\circ} \mathrm{C}$, with a corresponding mass loss $\Delta m=65.73 \%$, as evidenced by the two successive processes revealed by the DTG curve with maximums at 233 and $291^{\circ} \mathrm{C}$. In this range, the HF curve revealed an endothermic process $\left(187-219{ }^{\circ} \mathrm{C}, \mathrm{HF}_{\max }\right.$ at $\left.208^{\circ} \mathrm{C}\right)$. Later on, the last stage of decomposition $\left(369-510{ }^{\circ} \mathrm{C}\right)$ led to a residual mass of $4.06 \%$, and, with the advance of the thermal treatment, the exoergic process became more intense due to oxidative thermolysis $\left(\mathrm{HF}_{\max }\right.$ at $451^{\circ} \mathrm{C}$ and $\mathrm{DTG}_{\max }$ at $\left.486^{\circ} \mathrm{C}\right)$.

\subsection{Kinetic Investigations}

The screening of compatibility between the components in a multi-component system is really difficult to achieve by classic thermal analysis because the overlapping of thermal events due to an excipient can hide the events associated with the degradation of an API. Based on this fact, a comparative kinetic study of thermal degradation of the pure API vs. the same API incorporated in an existing pharmaceutical formulation (or in multicomponent system with excipients) could lead to important information regarding the stability of the API, as well as its compatibility/incompatibility with the system components [58]. 
Since the thermal stability of an API is different from the one of a solid pharmaceutical formulation, an in-depth kinetic study can reveal if the excipients determine the increase or the decrease of stability of CC after its incorporation in a tablet. In a previous paper, we investigated the solid-state stability of perindopril erbumine as a pure API and of perindopril erbumine in a pharmaceutical formulation, and we showed that the used excipients (anhydrous colloidal silica, microcrystalline cellulose, lactose, and magnesium stearate) should be used in newly-developed generic solid pharmaceutical formulations because they contributed to an increased thermal stability of perindopril erbumine [58].

The kinetic analysis was realized based on the DTG data that were obtained for the thermolysis in an oxidative atmosphere of $C C$ and CCTAB at four heating rates, namely $\beta=5,7,10$ and $12{ }^{\circ} \mathrm{C} \cdot \mathrm{min}^{-1}$.

As a first kinetic method, the ASTM E698 kinetic method was used. The ASTM E698 model is based on the Ozawa method, requires at least three experiments at different heating rates, and assumes that the extent of the reaction is a constant value independent of the heating rate when a DTG curve reaches its extreme value (DTG peak $)$. The mathematical model of the ASTM E698 method is presented in Equation (1):

$$
\ln \beta=\text { const }-1.052 \cdot E_{a} \cdot R^{-1} \cdot T_{\max }^{-1}
$$

where $\beta$ is the heating rate $\left({ }^{\circ} \mathrm{C} / \mathrm{min}\right.$ or equivalent $\left.\mathrm{K} / \mathrm{min}\right), E_{a}$ is the apparent activation energy $(\mathrm{kJ} / \mathrm{mol})$, $R$ is the gas constant, and $T_{\max }$ is the absolute temperature $(\mathrm{K})$ where extent of the reaction reaches its

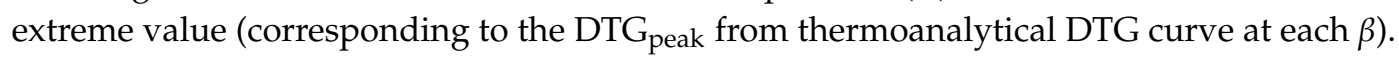

A plot of the natural logarithm of the heating rate vs. the peak temperature provides the information that is necessary to calculate the apparent activation energy (Ea), as shown in Figure 4a,b.

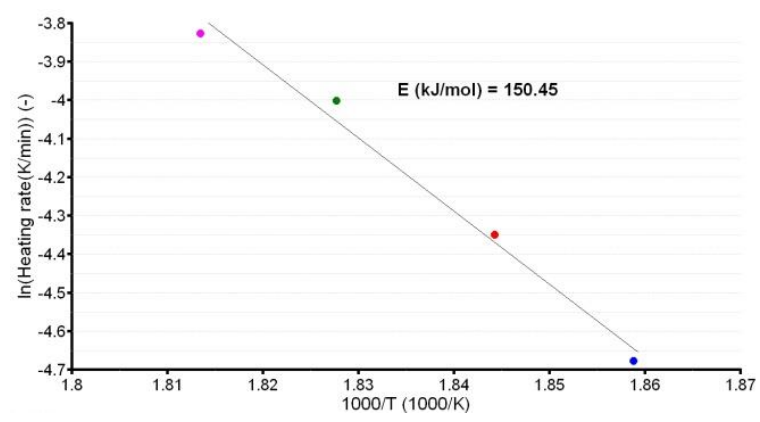

(a)

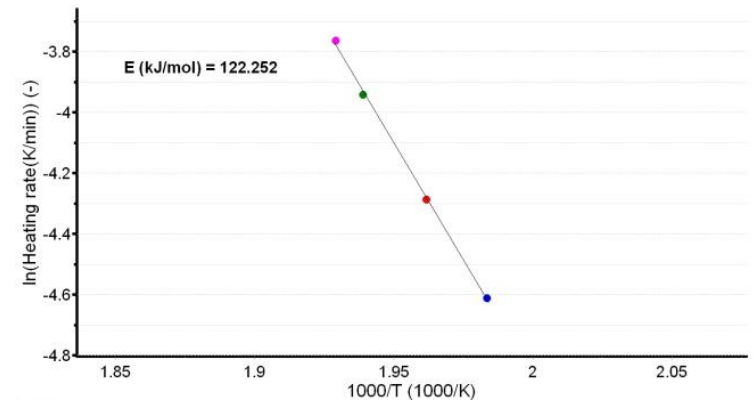

(b)

Figure 4. Linear plotting according to the American Society for Testing and Materials (ASTM) E698 kinetic method for CC (a) and CCTAB (b).

The linear dependencies obtained from the ASTM E698 kinetic method suggest a good correlation of the data, since the $R^{2}$ values were 0.988 for CC and 0.999 for CCTAB. Additionally, the estimated values of $E_{a}(150.5 \mathrm{~kJ} / \mathrm{mol}$ for CC and $122.3 \mathrm{~kJ} / \mathrm{mol}$ for CCTAB) suggested good thermal stability for CC as a pure API, as well as in pharmaceutical formulation. However, a small destabilizing effect of the excipients was observed, since the value obtained for formulation was approximately $28.2 \mathrm{~kJ} / \mathrm{mol}$ and thus inferior to that of pure CC.

Since International Confederation for Thermal Analysis and Calorimetry (ICTAC) protocols recommend the use of both differential and integral isoconversional methods to gain an in-depth view of decomposition kinetics-two isoconversional methods, a differential one (Friedman), and an integral one (Flynn-Wall-Ozawa) were employed in this study. The advantages and limitations of isoconversional methods have been reported in the literature [59-61]. By far, the most important advantage of using isoconversional methods is the fact that they assure the estimation of the apparent $E_{a}$ with the advance of the reaction (expressed as conversion degree $\alpha$ ) without assuming an approximation for the conversion function $\mathrm{f}(\alpha)$. Additionally, by the analysis of variation of individual $E_{a}$ values that 
are obtained for each $\alpha$, an indication for modification of degradation mechanism with the modification of thermal treatment is offered: iI each individual $E_{a}$ value that is determined for each $\alpha$ falls in the range of $\bar{E}_{a} \pm 0.1 \bar{E}_{a}$, the decomposition mechanism is not influenced by the modification of the thermal treatment of the sample and is independent of $\alpha$. If this premise is not true, the decomposition mechanism changes during the thermal treatment of the sample and is dependent of $\alpha$.

The reaction progress vs. temperature is presented in Figure 5a,b for the active substance and the pharmaceutical formulation. The variation of reaction rate vs. temperature for CC and CCTAB is presented in Figure 6a,b.

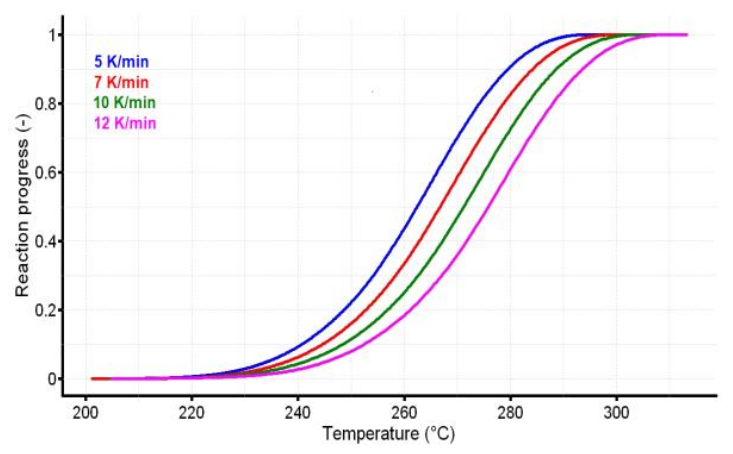

(a)

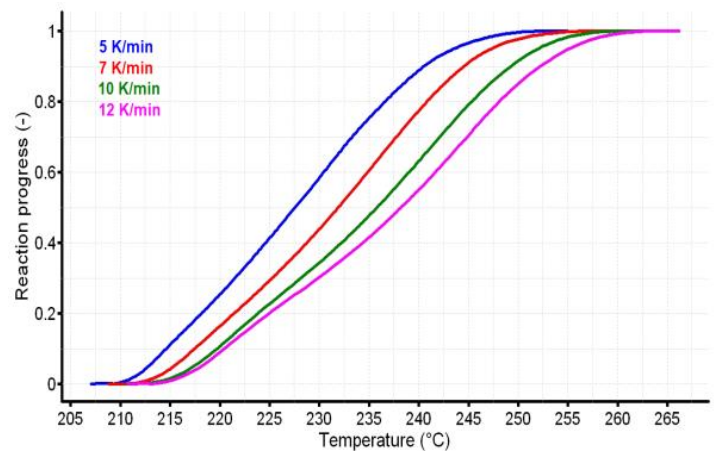

(b)

Figure 5. The reaction progress vs. temperature for (a) CC and (b) CCTAB.

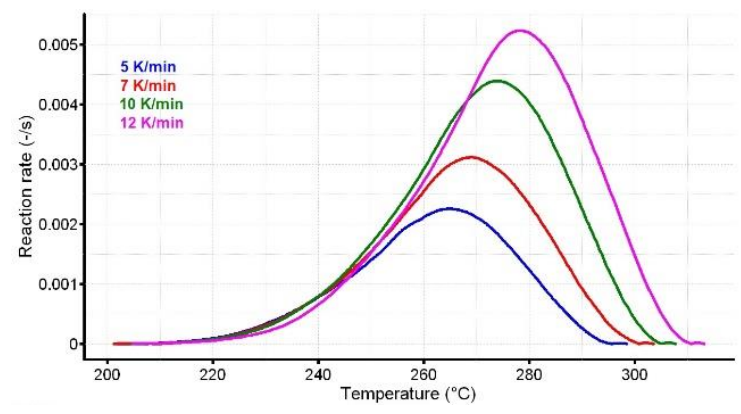

(a)

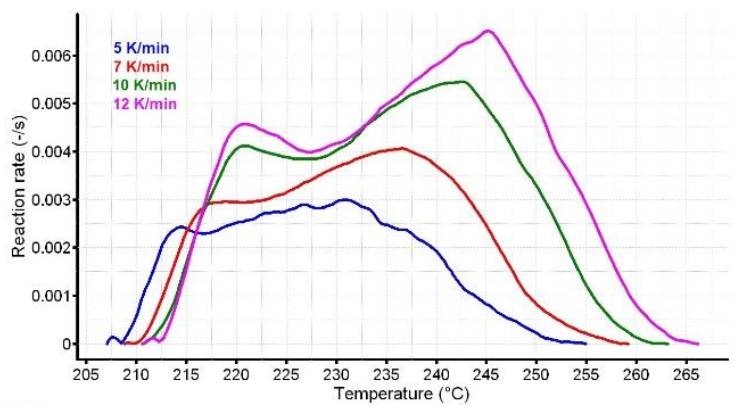

(b)

Figure 6. The variation of reaction rate vs. temperature for (a) CC and (b) CCTAB.

The analysis of variation of reaction rate vs. temperature may suggest different decomposition mechanisms for pure $\mathrm{CC}$ and $\mathrm{CCTAB}$; in the last case, this difference may have been due to the presence of excipients. The mathematical development of isoconversional methods, as well their deduction, were reported earlier [58,62]. The Friedman method (Fr) was used in the linearized form [63], as shown in Equation (2).

$$
\ln (\beta \cdot \mathrm{d} \alpha / \mathrm{d} T)=\ln [A \cdot \mathrm{f}(\alpha)]-E_{a} \cdot R^{-1} \cdot T^{-1}
$$

where $T$ is the absolute temperature $(\mathrm{K})$ and $A$ is the pre-exponential factor, as suggested by the Arrhenius equation.

For known $\alpha$ at the selected heating rates, the plot $\ln (\beta \cdot \mathrm{d} \alpha / \mathrm{d} T)$ vs. $(1 / T)$ was linear. The values of the apparent activation energy $\left(E_{a}\right)$ for the two samples were obtained (Table 1$)$ by evaluating the slopes of these straight lines (see Figure 7a,b). 
Table 1. Apparent activation energies values apparent activation energy $\left(E_{a}\right)$ vs. conversion degree $(\alpha)$ obtained by the isoconversional methods and the $\bar{E}_{a}$ value.

\begin{tabular}{|c|c|c|c|c|}
\hline \multirow{3}{*}{ Conversion Degree $\alpha$} & \multicolumn{4}{|c|}{$\mathrm{E}_{\mathrm{a}}(\mathrm{kJ} / \mathrm{mol})$ vs. $\alpha$ for } \\
\hline & \multicolumn{2}{|c|}{$\mathrm{CC}$} & \multicolumn{2}{|c|}{ ССТАВ } \\
\hline & Fr & FWO & Fr & FWO \\
\hline 0.05 & 152.9 & 168.5 & 197.0 & 307.3 \\
\hline 0.10 & 153.1 & 163.3 & 215.0 & 278.5 \\
\hline 0.15 & 152.1 & 160.3 & 215.7 & 263.6 \\
\hline 0.20 & 151.0 & 158.5 & 179.2 & 248.4 \\
\hline 0.25 & 151.3 & 157.1 & 133.1 & 227.6 \\
\hline 0.30 & 149.0 & 156.0 & 120.6 & 208.1 \\
\hline 0.35 & 149.2 & 155.1 & 112.7 & 192.1 \\
\hline 0.40 & 153.6 & 154.7 & 125.1 & 181.0 \\
\hline 0.45 & 155.8 & 154.9 & 126.3 & 173.6 \\
\hline 0.50 & 156.8 & 155.2 & 134.5 & 168.0 \\
\hline 0.55 & 157.3 & 155.5 & 140.6 & 164.6 \\
\hline 0.60 & 158.0 & 155.9 & 137.9 & 161.8 \\
\hline 0.65 & 158.5 & 156.3 & 144.8 & 159.6 \\
\hline 0.70 & 158.9 & 156.7 & 159.6 & 158.8 \\
\hline 0.75 & 158.6 & 157.0 & 176.1 & 160.2 \\
\hline 0.80 & 158.5 & 157.4 & 166.4 & 161.7 \\
\hline 0.85 & 157.8 & 157.7 & 161.1 & 161.7 \\
\hline 0.90 & 158.8 & 157.9 & 149.2 & 160.3 \\
\hline 0.95 & 162.8 & 158.6 & 201.3 & 163.7 \\
\hline $\bar{E}_{a}(\mathrm{~kJ} / \mathrm{mol})$ & $\begin{array}{c}155.5 \pm \\
0.9\end{array}$ & $\begin{array}{c}157.7 \pm \\
0.7\end{array}$ & $\begin{array}{c}157.7 \pm \\
7.2\end{array}$ & $\begin{array}{c}194.8 \pm \\
10.5\end{array}$ \\
\hline
\end{tabular}

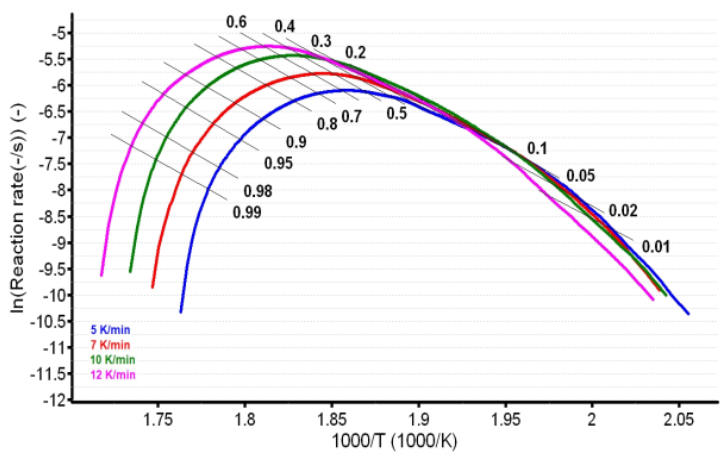

(a)

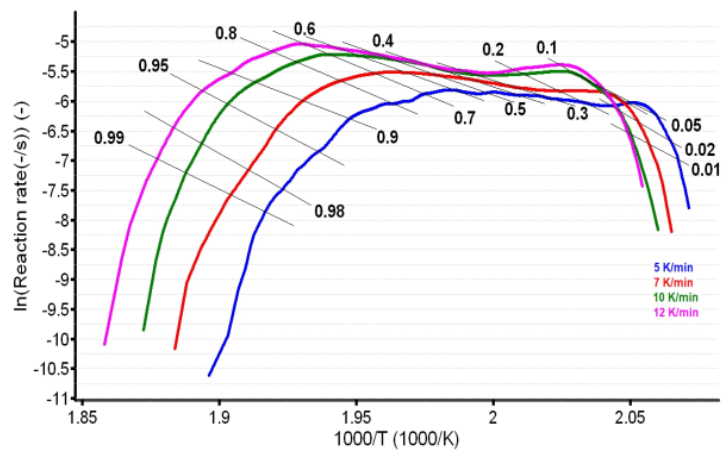

(b)

Figure 7. Plotting of Friedman method at selected four heating rates for (a) CC and (b) CCTAB.

The integral isoconversional method of Flynn-Wall-Ozawa (FWO) [64-67] was used in the linearized form presented in Equation (3):

$$
\ln \beta=\ln \left[A \cdot E_{a} \cdot R^{-1} \cdot \mathrm{g}^{-1}(\alpha)\right]-5.331-1.052 \cdot E_{a} \cdot R^{-1} \cdot T^{-1}
$$

where $\mathrm{g}(\alpha)$ is the integral conversion function.

The plotting of $\ln \beta$ vs. $\mathrm{T}^{-1}$ allowed for the estimation of apparent activation energy values $\left(E_{a}\right)$ for each conversion degree. The obtained results are presented in Figure $8 \mathrm{a}, \mathrm{b}$ and Table 1 . 




(a)

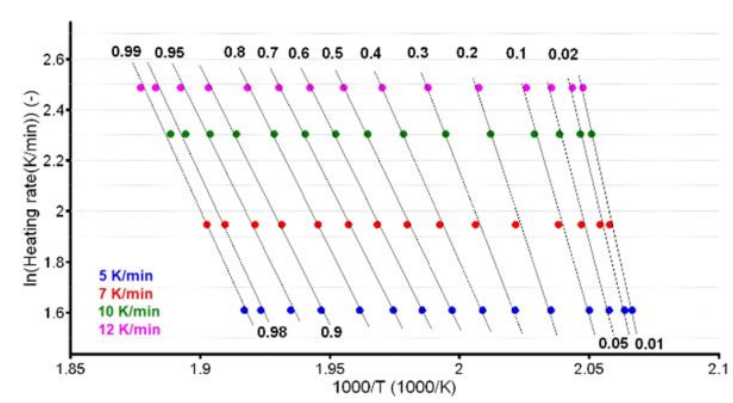

(b)

Figure 8. Plotting of Flynn-Wall-Ozawa method at selected four heating rates for (a) CC and (b) CCTAB.

In the case of $\mathrm{CC}$, both isoconversional methods indicate that the decomposition mechanism of the substance during thermolysis was unique and independent of the conversion degree and heating rate, since the values of individual $E_{a}$ values were around the mean value $(155.5 \mathrm{~kJ} / \mathrm{mol})$ and inside the $\pm 15 \mathrm{~kJ} / \mathrm{mol}$ interval (corresponding to confidence interval range $\bar{E}_{a} \pm 0.1 \bar{E}_{a}$ ), namely between $149.0 \mathrm{~kJ} / \mathrm{mol}$ (at $\alpha=30 \%$ ) and $162.8 \mathrm{~kJ} / \mathrm{mol}$ (at $\alpha=95 \%$ ), according to the Friedman method. The same trend was observed in the case of the integral method of FWO, where the variation was between $154.7 \mathrm{~kJ} / \mathrm{mol}$ (at $\alpha=40 \%$ ) and $168.5 \mathrm{~kJ} / \mathrm{mol}$ (at $\alpha=5 \%$ ), falling in the confidence interval around the mean value of $157.7 \mathrm{~kJ} / \mathrm{mol}$ (Table 1). Additionally, the results are in good agreement with the ASTM E698 method, as previously discussed.

In the case of $C C T A B$, the results indicated by the differential and integral method were not in good agreement, since the variation between the mean values was higher than $37 \mathrm{~kJ} / \mathrm{mol}$, clearly suggesting a complex pathway of decomposition. The particular values $E_{a}$ vs. $\alpha$ according to the Fr method did present a randomized trend with increases and decreases as the reaction advanced, so the maximum value was almost double the minimum $(215.7 \mathrm{~kJ} / \mathrm{mol}$ at $\alpha=15 \% \mathrm{vs} .112 .7 \mathrm{~kJ} / \mathrm{mol}$ at $\alpha=35 \%$ ). In this case, the mean $E_{a}$ value of $157.7 \mathrm{~kJ} / \mathrm{mol}$ was only calculated for a comparison to the result suggested by the FWO method and not to characterize the decomposition mechanism of the sample during thermal treatment, because, in this case, a modification of the mechanism during thermolysis occurred. The data suggested for the FWO method also clearly indicated the dependency of the mechanism of decomposition with the thermal treatment of the sample. The variation of the apparent $E_{a}$ fell between $158.8 \mathrm{~kJ} / \mathrm{mol}(\alpha=70 \%)$ and $307.3 \mathrm{~kJ} / \mathrm{mol}$ at the beginning of the decomposition process $(\alpha=5 \%)$. Most of the values $E_{a}$ vs. $\alpha$ were outside the confidence interval, and the mean value was in discrepancy with the results that were preliminarily obtained by the ASTM E698 method. The results obtained by the FWO method for CCTAB, namely the decrease of $E_{a}$ with the advance of reaction, can be explained by the variation of the parameters of activation during the heating process due to the complexity of the heterogeneous process and/or due to the influence of mass transfer and heat transfer over the reaction rate [68]. Vyazovkin et al. associated the trend and aspect of the $E_{a}$ vs. $\alpha$ curve with the mechanism of complex heterogenous processes, leading to important qualitative information over the thermolysis—so, for a variation like decreasing of $E_{a}$ vs. $\alpha$ (Figure 9), a process with reversible step is suspected [69-73].

Additionally, the considerable dissimilarities suggested by the Fr and FWO methods in the kinetic analysis of decomposition of CCTAB can be explained by the integral processing of the data in the case of integral method of FWO, in comparison to Friedman method, where the data processing is differential [58,62]. 


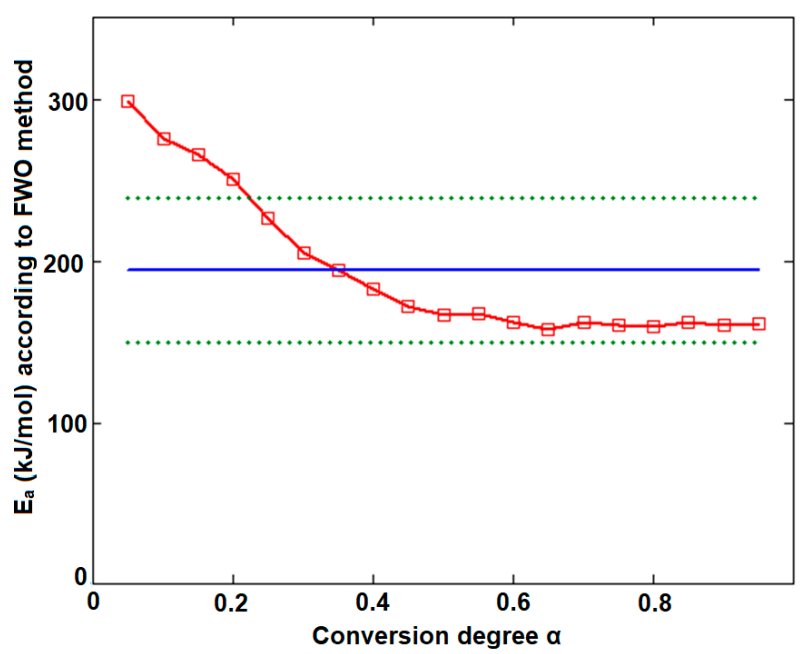

Figure 9. Plotting of Flynn-Wall-Ozawa method at selected four heating rates for CCTAB.

Since the results of kinetic studies (classic ASTM E698 method and isoconversional ones) were in disagreement, a fourth method was employed in the study, namely the modified NPK method. Initially, the NPK method was developed in 1998 through the studies of J. Sempere, R. Nomen and R. Serra [74-76] and carried on in a kinetic study on DSC data in isothermal conditions without using an a priori model for the $\mathrm{k}(T)$, nor for $\mathrm{f}(\alpha)$, and only accepting the axiom that the reaction rate $(r)$ can be expressed as a product of two separable functions-one dependent solely on temperature and one dependent solely on conversion, as shown in Equation (4):

$$
r=\frac{\mathrm{d} \alpha}{\mathrm{d} t}=\mathrm{k}(T) \cdot \mathrm{f}(\alpha)
$$

where $\mathrm{k}(T)$ is the rate constant and $\mathrm{f}(\alpha)$ is the differential conversion function.

Regarding the direct consequence for assuming the validity of this axiom (that is unanimously accepted in chemical kinetics), it worth mentioning two, namely the fact that the reaction rate can be represented as a 3D surface $(\Pi)$, and that the reaction rate can be expressed as a product of matrices.

Regarding the aforementioned first consequence by carrying the thermoanalytical experiments at several heating rates (in this case four), the results was a family of curves, by which interpolation generated the fitted 3D surface of the reaction rate $(\Pi)$, as seen in Figure 10.

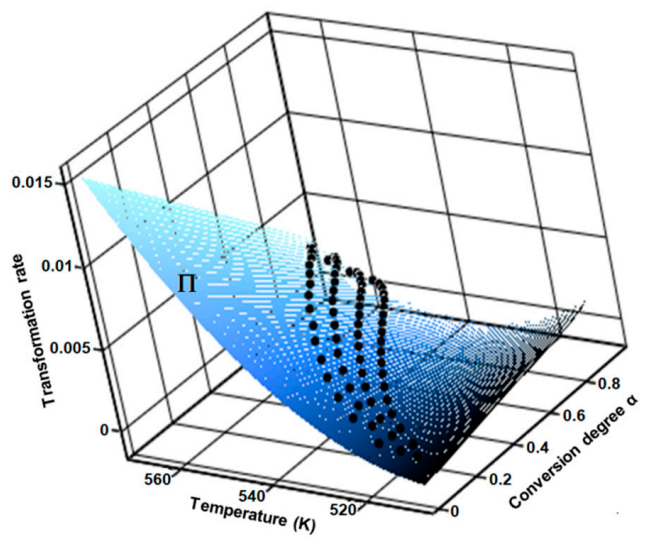

(a)

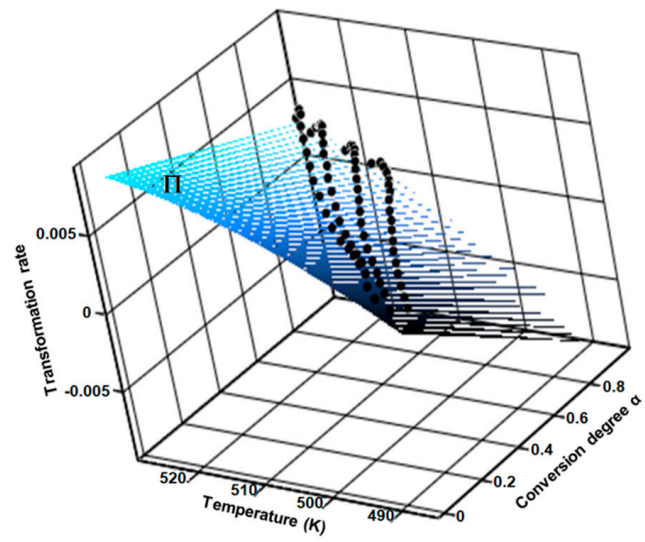

(b)

Figure 10. Surface of fitted 3D reaction rate generated by the interpolation of family of curves obtained at four selected heating rates for (a) CC and (b) CCTAB. 
Based on the validity of the axiom of kinetics presented in Equation (4), the modified NPK method was applied to the same data set as the previously employed kinetic methods. As a consequence, the reaction rates for the measurements at four different $\beta$ values can be written as a matrix with $n \times m$ elements whose rows correspond to the constant value of the conversion degree, and the columns correspond to the different but constant values of temperature. By using the singular value decomposition algorithm (SVD) [77], the corresponding matrix was decomposed into two vectors, leading to the separation of the two theoretically assumed functions, namely the temperature-dependent one (as $k(T))$ and the conversion-dependent one (as $\mathrm{f}(\alpha))$.

For the mathematical modelling of the two functions, any dependency can be theoretically used. However, for kinetics, the temperature dependence $\mathrm{k}(T)$ is usually represented by an Arrhenius model, while for the conversion function $\mathrm{f}(\alpha)$, the model proposed by Šesták and Berggren is usually used [78], as seen in Equation (5):

$$
\mathrm{f}(\alpha)=\alpha^{m} \cdot(1-\alpha)^{n}
$$

where $m$ and $n$ are specific parameters for the investigated transformation process, with $m$ corresponding to physical transformations (like phase transitions, crystallization, and diffusion) and $n$ corresponding to a chemical transformation (decomposition, dehydrations, condensation, oxidation, etc.).

The Šesták-Berggren model is a generalization of the conversion functions that were previously proposed and validated in literature, assuring the generality and universality of the modified NPK method and providing an advantage that can separate the physical and chemical events that occur during the transformation of a certain compound under thermal stress.

If a mass loss process evidenced by a TG curve consist in at least two simultaneous independent steps, then the apparent global rate of transformation $\left(r_{\text {global }}\right)$ is the sum of individual rates $\left(r_{1}, r_{2}, r_{3}\right.$ $\left.\ldots r_{z}\right)$, as long as the degradation process consists in $z$ individual steps Equation (6):

$$
r_{\text {global }}=\sum_{i=1}^{z} r_{i}
$$

and as a consequence, Equation (4) can be rewritten as Equation (7):

$$
r_{\text {global }}=\sum_{i=1}^{z} \mathrm{k}_{i}(T) \cdot \mathrm{f}_{i}(\alpha)
$$

This type of data processing is leading to $z$ sets of kinetic parameters $\left(E_{a}, A, m, n\right)$ and each process have a partial contribution to the global kinetic process, expressed as explained variance, $\lambda$.

Based on the mathematical model of the modified NPK method, the obtained results are systematized in Table 2, and the transformation rate surfaces in 3D dimensions with the coordinates $(\beta \cdot \mathrm{d} \alpha / \mathrm{d} T ; \alpha ; T)$ are presented in Figure 11.

The results obtained after employing the modified NPK method revealed that both samples, CC and $C C T A B$, were degraded by the contribution of the two distinct steps. However, these degradation was done via different mechanisms. In each case, the main step (characterized by the explained variances of $87.0 \%$ and $75.3 \%$, respectively) were due to chemical degradation, but they each had different reaction orders ( $n=1 / 3$ for CC and $n=1 / 4$ for CCTAB), suggesting different mechanisms as the most important contribution to the degradation process (for CC, the partial $E_{a}$ value due to this step was around $141.6 \mathrm{~kJ} / \mathrm{mol}$, while it was $149.2 \mathrm{~kJ} / \mathrm{mol}$ for CCTAB). The second process was represented by a physical transformation (since $n=0$ and $m \neq 0$ ), which can be attributed to the solid-liquid phase transition due to the melting of the API in both cases $\left(\mathrm{HF}_{\text {peak }}\right.$ at $\left.164^{\circ} \mathrm{C}\right)$. In the case of CCTAB, the value of $m$ changed in comparison to CC, as expected, since the HF curve revealed two more endoergic processes in this case due to the melting of excipients (peaks at 60 and $105^{\circ} \mathrm{C}$ ), along with the peak corresponding to the API. For both samples, the correlations obtained for the coefficient of determination for each step were excellent, thus proving the robustness of the kinetic model. 
Table 2. The results of kinetic analysis after employing the modified NPK method.

\begin{tabular}{|c|c|c|c|c|c|c|c|c|c|}
\hline Sample & Step & $\lambda(\%)$ & $A\left(\mathrm{~s}^{-1}\right)$ & $E_{\mathrm{a}}(\mathrm{kJ} / \mathrm{mol})$ & $n$ & $m$ & $\mathbf{R}^{2}$ & $f(\alpha)$ & $\bar{E}_{\mathrm{a}}(\mathrm{kJ} / \mathrm{mol})$ \\
\hline \multirow[t]{2}{*}{$\mathrm{CC}$} & 1 & 87.0 & $1.6 \times 10^{16} \pm 2.1 \times 10^{4}$ & $162.8 \pm 9.1$ & $1 / 3$ & 0 & 0.996 & $\begin{array}{l}(1- \\
x)^{1 / 3}\end{array}$ & \multirow[t]{2}{*}{$154.5 \pm 11.1$} \\
\hline & 2 & 8.5 & $8.6 \times 10^{13} \pm 4.4 \times 10^{9}$ & $147.2 \pm 2.0$ & 0 & $1 / 3$ & 0.996 & $x^{1 / 3}$ & \\
\hline \multirow[t]{2}{*}{ ССТАВ } & 1 & 75.3 & $9.6 \times 10^{20} \pm 4.5 \times 10^{6}$ & $198.2 \pm 11.5$ & $1 / 4$ & 0 & 0.993 & $\begin{array}{l}(1- \\
x)^{1 / 4}\end{array}$ & \multirow[t]{2}{*}{$192.5 \pm 16.6$} \\
\hline & 2 & 24.5 & $4.6 \times 10^{18} \pm 7.8 \times 10^{8}$ & $176.1 \pm 5.1$ & 0 & $5 / 3$ & 0.999 & $x^{5 / 3}$ & \\
\hline
\end{tabular}

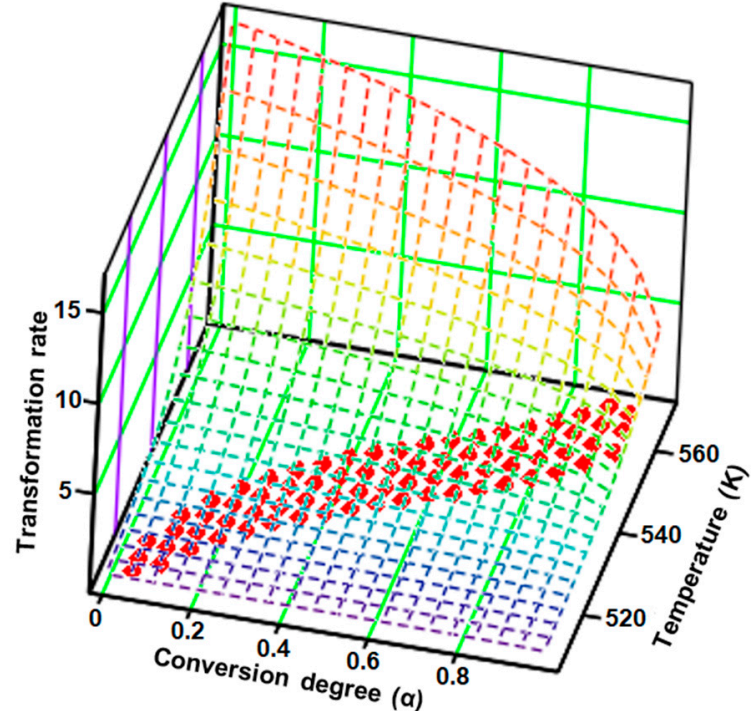

(a)

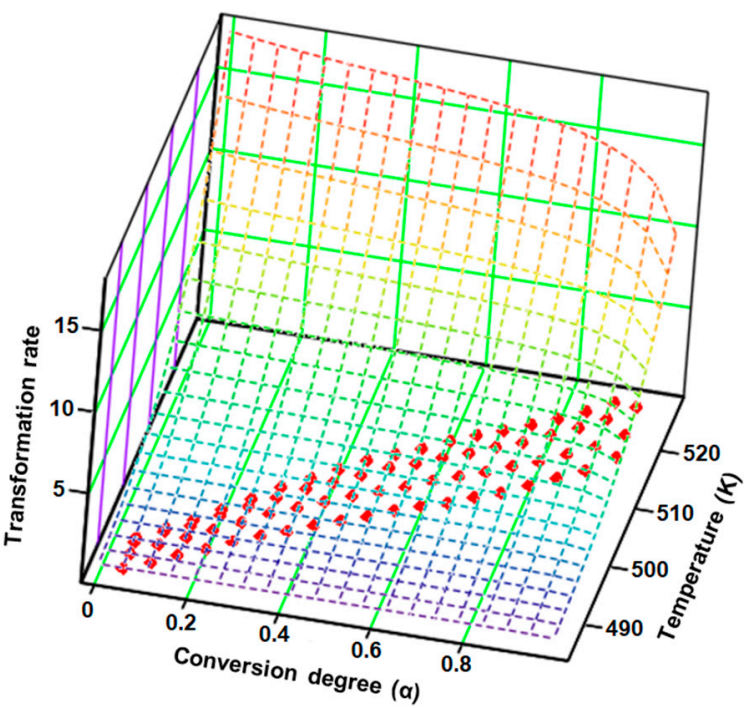

(b)

Figure 11. Experimental points (red dots) and the surface reaction generated by the kinetic parameters according to the modified non-parametric kinetics (NPK) method for (a) CC and (b) CCTAB.

\section{Conclusions}

In this paper, a comparative thermal stability analysis was carried out between candesartan cilexetil as a pure active pharmaceutical ingredient and a commercial pharmaceutical formulation containing $32 \mathrm{mg}$ of candesartan cilexetil per tablet. Initially, the samples were characterized by UATR-FTIR spectroscopy in order to check the identity and purity of the API and to investigate the possibly occurring interactions between the API and the excipients from the solid formulation. The results of the FTIR study confirmed the purity of CC and revealed that no interactions occurred between the API and the excipients from the tablet.

As second investigational tool, thermal analysis was chosen. Thermoanalytical curves TG/DTG/HF were drawn up at four different heating rates, and, initially, the thermal behavior of the two samples was investigated and discussed as observed at $\beta=5{ }^{\circ} \mathrm{C} / \mathrm{min}$. Due to the compositional complexity of the tablet, its thermoanalytical profile differed significantly to the one of API, though this profile did reveal some of the characteristics of CC.

Since the kinetic study led to some inadvertencies regarding the stability of the API in the tablet in comparison to CC, four methods were employed to analyze the decomposition behavior of both samples, starting with classic methods (ASTM E698) and finishing with the modified NPK method, the later one providing important information regarding thermolysis, including the mechanism of decomposition.

In comparison to the kinetic results suggested by previously-chosen methods (ASTM E698, Fr and FWO), the ones offered by NPK were in agreement for CC in all cases; for CCTAB, the results 
confirmed the data suggested by the FWO method, namely a stabilizing effect on the decomposition of CC in CCTAB relative to CC due to the presence of excipients in pharmaceutical formulation. The NPK method suggested that both samples were degraded by the contribution of two steps, the main step being chemical degradation and the secondary step being a physical transformation. The excipients chosen in the formulation seemed to have a stabilizing effect, since the apparent activation energy for decomposition of the tablet was $192.5 \mathrm{~kJ} / \mathrm{mol}$, and the apparent activation energy for decomposition of pure API was $154.5 \mathrm{~kJ} / \mathrm{mol}$.

Author Contributions: Conceptualization, V.B., B.B., M.A., D.E.M., A.L., F.P. and I.L.; methodology, all authors; software, G.V. and T.V.; validation, V.B., B.B., G.V., T.V., C.D. and P.M.; formal analysis, all authors; investigation, all authors; resources, all authors; data curation, V.B., B.B., M.A., D.E.M., A.L., F.P. and I.L.; writing-original draft preparation, V.B., B.B., M.A., D.E.M., A.L., C.D., P.M., F.P. and I.L.; writing-review and editing, V.B., B.B., M.A., D.E.M., A.L., F.P. and I.L.; visualization, all authors; supervision, F.P. and I.L. All authors have read and agreed to the published version of the manuscript.

Funding: This work was supported by a grant from the University of Medicine and Pharmacy "Victor Babeş" Timişoara (PII-C4-TC-2016-16441-09 to Valentina Buda).

Conflicts of Interest: The authors declare no conflict of interest.

\section{References}

1. Bulsara, K.G.; Makaryus, A.N. Candesartan; StatPearls Publishing: Treasure Island, FL, USA, 2018.

2. Takezako, T.; Unal, H.; Karnik, S.S.; Node, K. Current topics in angiotensin II type 1 receptor research: Focus on inverse agonism, receptor dimerization and biased agonism. Pharmacol. Res. 2017, 123, 40-50. [CrossRef]

3. Gleiter, C.H.; Jägle, C.; Gresser, U.; Mörike, K. Candesartan. Cardiovasc. Drug Rev. 2004, 22, $263-284$. [CrossRef]

4. Gavras, H. Update on the clinical pharmacology of candesartan cilexetil. Am. J. Hypertens. 2000, 13, S25-S30. [CrossRef]

5. Zhao, D.; Liu, H.; Dong, P. A Meta-analysis of antihypertensive effect of telmisartan versus candesartan in patients with essential hypertension. Clin. Exp. Hypertens. 2019, 41, 75-79. [CrossRef] [PubMed]

6. Isobe, N.; Taniguchi, K.; Oshima, S.; Ono, Z.; Adachi, H.; Toyama, T.; Naito, S.; Hoshizaki, H.; Kamiyama, H. Candesartan cilexetil improves left ventricular function, left ventricular hypertrophy, and endothelial function in patients with hypertensive heart disease. Circ. J. 2002, 66, 993-999. [CrossRef] [PubMed]

7. Pfeffer, M.A.; Swedberg, K.; Granger, C.B.; Held, P.; McMurray, J.J.V.; Michelson, E.L.; Olofsson, B.; Östergren, J.; Yusuf, S. Effects of candesartan on mortality and morbidity in patients with chronic heart failure: The CHARM-overall programme. Lancet 2003, 362, 759-766. [CrossRef]

8. Donaire, J.A.G.; Ruilope, L.M. Angiotensin receptor blockade in diabetic renal disease-Focus on candesartan. Diabetes Res. Clin. Pract. 2007, 76, S22-S30. [CrossRef] [PubMed]

9. Behl, T.; Kotwani, A. Potential of angiotensin II receptor blockers in the treatment of diabetic retinopathy. Life Sci. 2017, 176, 1-9. [CrossRef] [PubMed]

10. Gullo, C.E.; de Almeida Zia, V.A.; Vilela-Martin, J.F. Blockade of renin angiotensin system in heart failure post-myocardial infarction: What is the best therapy? Recent Pat. Cardiovasc. Drug Discov. 2014, 9, $28-37$. [CrossRef]

11. Buda, V.; Andor, M.; Cristescu, C.; Voicu, M.; Cochera, F.; Tuduce, P.; Petrescu, L.; Tomescu, M.C. The effect of candesartan on pentraxin-3 plasma levels as marker of endothelial dysfunction in patients with essential arterial hypertension. Ir. J. Med. Sci. 2017, 186, 621-629. [CrossRef]

12. Chen, T.; Yu, D.; Cornelius, V.; Qin, R.; Cai, Y.; Jiang, Z.; Zhao, Z. Potential health impact and cost-effectiveness of drug therapy for prehypertension. Int. J. Cardiol. 2017, 240, 403-408. [CrossRef] [PubMed]

13. Ducharme, A.; Swedberg, K.; Pfeffer, M.A.; Cohen-Solal, A.; Granger, C.B.; Maggioni, A.P.; Michelson, E.L.; McMurray, J.J.V.; Olsson, L.; Rouleau, J.L.; et al. Prevention of atrial fibrillation in patients with symptomatic chronic heart failure by candesartan in the Candesartan in Heart failure: Assessment of Reduction in Mortality and morbidity (CHARM) program. Am. Heart J. 2006, 152, 86-92. [CrossRef] [PubMed]

14. Stovner, L.J.; Linde, M.; Gravdahl, G.B.; Tronvik, E.; Aamodt, A.H.; Sand, T.; Hagen, K. A comparative study of candesartan versus propranolol for migraine prophylaxis: A randomised, triple-blind, placebo-controlled, double cross-over study. Cephalalgia 2014, 34, 523-532. [CrossRef] [PubMed] 
15. Venkat, P.; Shen, Y.; Chopp, M.; Chen, J. Cell-based and pharmacological neurorestorative therapies for ischemic stroke. Neuropharmacology 2018, 134, 310-322. [CrossRef]

16. Torika, N.; Asraf, K.; Apte, R.N.; Fleisher-Berkovich, S. Candesartan ameliorates brain inflammation associated with Alzheimer's disease. CNS Neurosci. Ther. 2018, 24, 231-242. [CrossRef]

17. Perez-Lloret, S.; Otero-Losada, M.; Toblli, J.E.; Capani, F. Renin-angiotensin system as a potential target for new therapeutic approaches in Parkinson's disease. Expert Opin. Investig. Drugs 2017, 26, 1163-1173. [CrossRef]

18. Kim, M.J.; Im, D.S. Suppressive effects of type I angiotensin receptor antagonists, candesartan and irbesartan on allergic asthma. Eur. J. Pharmacol. 2019, 852, 25-33. [CrossRef]

19. Zhao, X.; Wang, X. Candesartan targeting of angiotensin II type 1 receptor demonstrates benefits for hypertension in pregnancy via the NF-KB signaling pathway. Mol. Med. Rep. 2018, 18, 705-714. [CrossRef]

20. Candesartan on Drugs.com. Available online: https://www.drugs.com/mtm/candesartan.html (accessed on 27 November 2019).

21. Pinto, E.C.; do Carmo, F.A.; da Honório, T.S.; de da Barros, R.C.S.A.; Castro, H.C.R.; Rodrigues, C.R.; Esteves, V.S.D.; Rocha, H.V.A.; de Sousa, V.P.; Cabral, L.M. Influence of the Efavirenz Micronization on Tableting and Dissolution. Pharmaceutics 2012, 4, 430-441. [CrossRef]

22. Viet Nguyen, K.; Laidmäe, I.; Kogermann, K.; Lust, A.; Meos, A.; Viet Ho, D.; Raal, A.; Heinämäki, J.; Thi Nguyen, H. Preformulation Study of Electrospun Haemanthamine-Loaded Amphiphilic Nanofibers Intended for a Solid Template for Self-Assembled Liposomes. Pharmaceutics 2019, 11, 499. [CrossRef]

23. Modhave, D.; Barrios, B.; Paudel, A. PVP- $\mathrm{H}_{2} \mathrm{O}_{2}$ Complex as a New Stressor for the Accelerated Oxidation Study of Pharmaceutical Solids. Pharmaceutics 2019, 11, 457. [CrossRef] [PubMed]

24. Oliveira, L.J.; Stofella, N.C.F.; Veiga, A.; Federle, S.; da Toledo, M.G.T.; Bernardi, L.S.; Oliveira, P.R.; Carvalho Filho, M.A.S.; Andreazza, I.F.; Murakami, F.S. Physical-chemical characterization studies of ketoprofen for orodispersible tablets. J. Therm. Anal. Calorim. 2018, 133, 1521-1533. [CrossRef]

25. Ledeţi, I.; Ledeţi, A.; Vlase, G.; Vlase, T.; Matusz, P.; Bercean, V.; Şuta, L.-M.; Piciu, D. Thermal stability of synthetic thyroid hormone l-thyroxine and l-thyroxine sodium salt hydrate both pure and in pharmaceutical formulations. J. Pharm. Biomed. Anal. 2016, 125, 33-40. [CrossRef] [PubMed]

26. Bandas (Ratiu), C.; Orha, C.; Misca, C.; Lazau, C.; Sfirloaga, P.; Olariu, S. Photocatalytical Inactivation of Enterococcus faecalis from Water Using Functional Materials Based on Natural Zeolite and Titanium Dioxide. Chin. J. Chem. Eng. 2014, 22, 38-43. [CrossRef]

27. Faya, P.; Seaman, J.W.; Stamey, J.D. Using accelerated drug stability results to inform long-term studies in shelf life determination. Stat. Med. 2018, 37, 2599-2615. [CrossRef]

28. Zilker, M.; Sörgel, F.; Holzgrabe, U. A systematic review of the stability of finished pharmaceutical products and drug substances beyond their labeled expiry dates. J. Pharm. Biomed. Anal. 2019, 166, 222-235. [CrossRef]

29. Ledeti, I.; Pusztai, A.M.; Murariu, M.; Olariu, S.; Ivan, C.; Circioban, D.; Vlase, G.; Ledeti, A.; Vlase, T.; Matusz, P. Comparative instrumental investigations of some bile acids. J. Therm. Anal. Calorim. 2018, 134, 1345-1350. [CrossRef]

30. Ledeti, A.; Vlase, G.; Vlase, T.; Circioban, D.; Dehelean, C.; Ledeti, I.; Suta, L.M. Binary adduct formation of desipramine with dicarboxylic acids: An instrumental study. J. Therm. Anal. Calorim. 2018, 131, 167-173. [CrossRef]

31. Ledeti, I.; Bolintineanu, S.; Vlase, G.; Circioban, D.; Ledeti, A.; Vlase, T.; Suta, L.M.; Caunii, A.; Murariu, M. Compatibility study between antiparkinsonian drug Levodopa and excipients by FTIR spectroscopy, X-ray diffraction and thermal analysis. J. Therm. Anal. Calorim. 2017, 130, 433-441. [CrossRef]

32. Ledeti, I.; Pusztai, A.M.; Muresan, C.M.; Circioban, D.; Vlase, G.; Murariu, M.; Suta, L.-M.; Vlase, T.; Ledeti, A.; Suciu, O.; et al. Study of solid-state degradation of prochlorperazine and promethazine. J. Therm. Anal. Calorim. 2018, 134, 731-740. [CrossRef]

33. Wu, C.; You, J.; Wang, X. Study on the thermal decomposition of famciclovir. J. Therm. Anal. Calorim. 2018, 131, 1361-1371. [CrossRef]

34. Dartora, P.C.; da Loureiro, M.R.; de Camargo Forte, M.M. Crystallization kinetics and morphology of poly(lactic acid) with polysaccharide as nucleating agent. J. Therm. Anal. Calorim. 2018, 134, 1705-1713. [CrossRef] 
35. Moisei, A.; Gligor, F.; Bojiţă, M.; Chiş, A.; Totan, M.; Vonica-Gligor, L.A.; Ciurba, A. Compatibility and stability studies of antihypertensive/excipients by thermal methods, Used in the preformulation phase. Farmacia 2014, 62, 1239-1248.

36. Amer, A.M.; Allam, A.N.; Abdallah, O.Y. Comparative Pharmaceutical Evaluation of Candesartan and Candesartan Cilexetil: Physicochemical Properties, In Vitro Dissolution and Ex Vivo In Vivo Studies. AAPS PharmSciTech 2018, 19, 661-667. [CrossRef]

37. Tita, I.C.; Marian, E.; Tita, B.; Toma, C.C.; Vicas, L. Thermal Behaviour of Candesartan Active substance and in pharmaceutical compounds. Rev. Chim. 2017, 68, 1895-1902.

38. Sharma, G.; Beg, S.; Thanki, K.; Katare, O.P.; Jain, S.; Kohli, K.; Singh, B. Systematic development of novel cationic self-nanoemulsifying drug delivery systems of candesartan cilexetil with enhanced biopharmaceutical performance. RSC Adv. 2015, 5, 71500-71513. [CrossRef]

39. Yuce, M.; Guven, O.; Karahan, S.; Saracbasi, O.; Capan, Y. Preformulation of Immediate Release Candesartan Cilexetil Tablets Using Full Factorial Experimental Design. Lat. Am. J. Pharm. 2016, 35, 921-930.

40. Cui, P.; Yin, Q.; Guo, Y.; Gong, J. Polymorphic crystallization and transformation of candesartan cilexetil. Ind. Eng. Chem. Res. 2012, 51, 12910-12916. [CrossRef]

41. Ledeti, I.; Murariu, M.; Vlase, G.; Vlase, T.; Doca, N.; Ledeti, A.; Suta, L.-M.; Olariu, T. Investigation of thermal-induced decomposition of iodoform. J. Therm. Anal. Calorim. 2017, 127, 565-570. [CrossRef]

42. Nozela, W.C.; Nozela, C.F.V.; Silva, F.R.; Dias, D.S.; Almeida, S.; Ribeiro, C.A.; Crespi, M.S. Kinetic study of the energetic reuse from torrefied sewage sludge and urban pruning blends. J. Therm. Anal. Calorim. 2018, 134, 1285-1291. [CrossRef]

43. El-Sadek, M.H.; Ahmed, H.M.; El-Barawy, K.; Morsi, M.B.; El-Didamony, H.; Bjorkman, B. Non-isothermal carbothermic reduction kinetics of mechanically activated ilmenite containing self-reducing mixtures. $J$. Therm. Anal. Calorim. 2018, 131, 2457-2465. [CrossRef]

44. Mothe, C.G.; de Miranda, I.C. Decomposition through pyrolysis process of coconut fiber and rice husk and determination of kinetic parameters according isoconversional methods. J. Therm. Anal. Calorim. 2018, 131, 601-609. [CrossRef]

45. Antar, K.; Jemal, M. A thermogravimetric study into the effects of additives and water vapor on the reduction of gypsum and Tunisian phosphogypsum with graphite or coke in a nitrogen atmosphere. J. Therm. Anal. Calorim. 2018, 132, 113-125. [CrossRef]

46. Erceg, M.; Kresic, I.; Vrandecic, N.S.; Jakic, M. Different approaches to the kinetic analysis of thermal degradation of poly(ethylene oxide). J. Therm. Anal. Calorim. 2018, 131, 325-334. [CrossRef]

47. Ledeţi, I.; Fuliaş, A.; Vlase, G.; Vlase, T.; Bercean, V.; Doca, N. Thermal behavior and kinetic study of some triazoles as potential anti-inflammatory agents. J. Therm. Anal. Calorim. 2013, 114, 1295-1305. [CrossRef]

48. Ledeti, I.; Vlase, G.; Vlase, T.; Doca, N.; Bercean, V.; Fulias, A. Thermal decomposition, kinetic study and evolved gas analysis of 1,3,5-triazine-2,4,6-triamine. J. Therm. Anal. Calorim. 2014, 118, 1057-1063. [CrossRef]

49. Ledeţi, I.; Vlase, G.; Vlase, T.; Fuliaş, A. Kinetic analysis of solid-state degradation of pure pravastatin versus pharmaceutical formulation. J. Therm. Anal. Calorim. 2015, 121, 1103-1110. [CrossRef]

50. Circioban, D.; Ledeţi, I.; Vlase, G.; Ledeţi, A.; Axente, C.; Vlase, T.; Dehelean, C. Kinetics of heterogeneous-induced degradation for artesunate and artemether. J. Therm. Anal. Calorim. 2018, 134, 749-756. [CrossRef]

51. Vlase, T.; Albu, P.; Ledeti, A.; Circioban, D.; Mateescu, M.; Mosoiu, C.; Vlase, G. Thermal behavior of entacapone, a catechol-O-methyltransferase inhibitor used in Parkinson's disease. J. Therm. Anal. Calorim. 2018, 134, 711-720. [CrossRef]

52. Ledeţi, I.; Vlase, G.; Vlase, T.; Bercean, V.; Fuliaş, A. Kinetic of solid-state degradation of transitional coordinative compounds containing functionalized 1,2,4-triazolic ligand. J. Therm. Anal. Calorim. 2015, 121, 1049-1057. [CrossRef]

53. Ardiana, F.; Lestari, M.L.A.D.; Indrayanto, G. Candesartan Cilexetil. In Profiles of Drug Substances, Excipients and Related Methodology; Brittain, H.G., Ed.; Profiles of Drug Substances, Excipients and Related Methodology; Academic Press: Cambridge, MA, USA, 2012; Volume 37, pp. 79-112.

54. Silverstein, R.M.; Webster, F.X.; Kiemle, D. Spectrometric Identification of Organic Compounds, 7th ed.; Wiley: Hoboken, NY, USA, 2005; pp. 72-125. ISBN 0-471-39362-2.

55. Chi, Y.; Xu, W.; Yang, Y.; Yang, Z.; Lv, H.; Yang, S.; Lin, Z.; Li, J.; Gu, J.; Hill, C.L.; et al. Three Candesartan Salts with Enhanced Oral Bioavailability. Cryst. Growth Des. 2015, 15, 3707-3714. [CrossRef] 
56. Svetlik, J.; Martvon, A.; Lesko, J. Preparation and Spectral Properties of Tetrazoles. Chem. Zvesti 1979, 33, 521-527.

57. Shaikh, S.M.; Avachat, A.M. Enhancement of Solubility and Permeability of Candesartan Cilexetil by Using Different Pharmaceutical Interventions. Curr. Drug Deliv. 2011, 8, 346-353. [CrossRef] [PubMed]

58. Buda, V.; Andor, M.; Ledeti, A.; Ledeti, I.; Vlase, G.; Vlase, T.; Cristescu, C.; Voicu, M.; Suciu, L.; Tomescu, M.C. Comparative solid-state stability of perindopril active substance vs. pharmaceutical formulation. Int. J. Mol. Sci. 2017, 18, 164. [CrossRef]

59. Budrugeac, P.; Segal, E. On the Li and Tang's isoconversional method for kinetic analysis of solid-state reactions from thermoanalytical data. J. Mater. Sci. 2001, 36, 2707-2710. [CrossRef]

60. Budrugeac, P.; Homentcovschi, D.; Segal, E. Critical analysis of the isoconversional methods for evaluating the activation energy. I. Theoretical background. J. Therm. Anal. Calorim. 2001, 63, 457-463. [CrossRef]

61. Budrugeac, P.; Segal, E. Applicability of the Kissinger equation in thermal analysis. J. Therm. Anal. Calorim. 2007, 88, 703-707. [CrossRef]

62. Ledeţi, I.; Alexa, A.; Bercean, V.; Vlase, G.; Vlase, T.; Şuta, L.M.; Fuliaş, A. Synthesis and degradation of Schiff bases containing heterocyclic pharmacophore. Int. J. Mol. Sci. 2015, 16, 1711-1727. [CrossRef]

63. Friedman, H.L. New methods for evaluating kinetic parameters from thermal analysis data. J. Polym. Sci. Part B Polym. Lett. 1969, 7, 41-46. [CrossRef]

64. Ozawa, T. Estimation of activation energy by isoconversion methods. Thermochim. Acta 1992, 203, 159-165. [CrossRef]

65. Ozawa, T. A New Method of Analyzing Thermogravimetric Data. Bull. Chem. Soc. Jpn. 1965, 38, 1881-1886. [CrossRef]

66. Flynn, J.H. The isoconversional method for determination of energy of activation at constant heating rates-Corrections for the Doyle approximation. J. Therm. Anal. 1983, 27, 95-102. [CrossRef]

67. Flynn, J.H.; Wall, L.A. A quick, direct method for the determination of activation energy from thermogravimetric data. J. Polym. Sci. Part B Polym. Lett. 1966, 4, 323-328. [CrossRef]

68. Galwey, A.K. What is meant by the term 'variable activation energy' when applied in the kinetic analyses of solid state decompositions (crystolysis reactions)? Thermochim. Acta 2003, 397, 249-268. [CrossRef]

69. Vyazovkin, S.V.; Lesnikovich, A.I. An approach to the solution of the inverse kinetic problem in the case of complex processes. Part 1. Methods employing a series of thermoanalytical curves. Thermochim. Acta 1990, 165, 273-280. [CrossRef]

70. Vyazovkin, S.V.; Goryachko, V.I.; Lesnikovich, A.I. An approach to the solution of the inverse kinetic problem in the case of complex processes. Part III. Parallel independent reactions. Thermochim. Acta 1992, 197, 41-51. [CrossRef]

71. Vyazovkin, S.; Goryachko, V. Potentialities of software for kinetic processing of thermoanalytical data by the isoconversion method. Thermochim. Acta 1992, 194, 221-230. [CrossRef]

72. Vyazovkin, S.; Linert, W. Kinetic-analysis of reversible thermal-decomposition of solids. Int. J. Chem. Kinet. 1995, 27, 73-84. [CrossRef]

73. Vyazovkin, S.; Wight, C.A. Kinetics in solids. Annu. Rev. Phys. Chem. 1997, 48, 125-149. [CrossRef]

74. Serra, R.; Sempere, J.; Nomen, R. A new method for the kinetic study of thermoanalytical data: The non-parametric kinetics model. Thermochim. Acta 1998, 316, 37-45. [CrossRef]

75. Serra, R.; Sempere, J.; Nomen, R. The non-parametric kinetics. A new method for the kinetic study of thermoanalytical data. J. Therm. Anal. 1998, 52, 933-943. [CrossRef]

76. Sempere, J.; Nomen, R.; Serra, R. Progress in non-parametric kinetics. J. Therm. Anal. Calorim. 1999, 56, 843-849. [CrossRef]

77. Wall, M.E.; Rechtsteiner, A.; Rocha, L.M. Singular value decomposition and principal component analysis. In A Practical Approach to Microarray Data Analysis; Berrar, D.P., Dunitzky, W., Granzow, M., Eds.; Kluwer: Alfen am Rhein, The Netherlands, 2003; pp. 91-109. ISBN 1402072600.

78. Sestak, J.; Berggren, G. Study of the kinetics of the mechanism of solid-state reactions at increasing temperatures. Thermochim. Acta 1971, 3,1-12. [CrossRef]

(C) 2020 by the authors. Licensee MDPI, Basel, Switzerland. This article is an open access article distributed under the terms and conditions of the Creative Commons Attribution (CC BY) license (http://creativecommons.org/licenses/by/4.0/). 